\title{
38. SITE 398: EVOLUTION OF THE WEST IBERIAN PASSIVE CONTINENTAL MARGIN IN THE FRAMEWORK OF THE EARLY EVOLUTION OF THE NORTH ATLANTIC OCEAN ${ }^{1}$
}

\author{
Jean-Claude Sibuet, Centre Océanologique de Bretagne, B.P. 337, 29273, Brest, Cedex, France \\ and \\ William B.F. Ryan, Lamont Doherty Geological Observatory, Palisades, New York
}

\section{INTRODUCTION}

DSDP Site 398 is located on the West Iberian passive continental margin, south of Galicia Bank, $20 \mathrm{~km}$ to the south of Vigo Seamount (Figure 1). The kinematic evolution of the Iberian plate is closely controlled by the relative motions of the African, European, and North American plates. A study based on magnetic data and land data was undertaken to better define the relative motion of Iberia with respect to these main plates (Sibuet et al., in preparation). Trapped between these plates, microcontinents such as Galicia Bank and Flemish Cap (located between Iberia and North America) assumed their own relative motions with respect to Iberia and North America during the early evolution of the North Atlantic. Consequently, the initial oceanic circulation between small basins corresponding to the Bay of Biscay and the North Atlantic west of Iberia and Europe is closely controlled by relative positions and movements of these microcontinents. Site 398 paleoenvironment data, therefore, are of crucial interest in understanding the early evolution of the North Atlantic and the vertical evolution of continental margins.

\section{ACOUSTIC STRATIGRAPHY}

Site 398 was drilled about 400 meters laterally off the IFP-CNEXO Flexichoc seismic line GP 19 near shotpoint 440 (Figure 2, see location on Figure 1), in a water depth of 3900 meters. A total penetration of 1740 meters was obtained. Four main acoustic units (Figure 2) lie over the acoustic basement (Groupe Galice, this volume).

The acoustic basement is clearly of sedimentary origin on this profile. It is highly diffractive in most places and shows strong relief either as broad undulations or as sharp crests corresponding to buried highs. Some of these highs may even outcrop as shown on some seismic profiles. Sharp crests and strongly dipping layers in the basement suggest the presence of tilted fault blocks frequently observed over passive margins. On some profiles, several highs are flat-topped and covered by a thin sedimentary blanket which suggests that they have been affected by subaerial erosion.

Formation 4, which is a moderately to strongly layered formation, is separated from the overlying Forma-

\footnotetext{
${ }^{1}$ Contribution 616 of the Scientific Department of the Centre Océanologique de Bretagne.
}

tion 3 by a strong reflector. Formation 4 lies in troughs between horsts and tilted blocks. Layering is quite conformable between its base and the top of the basement in the lowest part of the fill. At the top, it can be almost flat. This indicates that sedimentation occurred as basement blocks were being tilted.

Formation 3 is generally transparent or slightly layered. It fills depressions similar to Formation 4, but actually differs from it by its less inclined or even horizontal bedding. It may be absent on top of some structural highs.

Formation 2 often seems to have been deposited on an almost flat topography. It is a layered sequence marked by several good reflectors. Bedding is generally flat and conformable with the lower boundary.

Formation 1 is acoustically transparent on top (acoustic Unit 1A). Layering increases towards the base (acoustic Unit 1B) where it merges into Formation 2.

\section{STRATIGRAPHY FROM PISTON CORES, DREDGE SAMPLES, AND HOLE 398D CORES}

The acoustic formations just described can be related to the lithologic column of Site 398 and to the stratigraphy obtained from core and dredge samples (Dupeuble et al., 1976 and this volume; Site 398 Report; Groupe Galice; de Graciansky and Chenet; Sigal; Maldonado; all, this volume).

Based upon correlations between lithologic and acoustic units, stratigraphic and seismic hiatuses, physical properties, mineralogical composition of sediments, and acoustic impedance, the proposition has been made that the lowermost 73 meters were drilled into acoustic basement (Site 398 Report; Bouquigny and Willm, both, this volume). This lowermost section consists of a complex sequence of marlstone, siltstone, and white indurated limestone of late Hauterivian to early Barremian age. The white indurated limestones were deposited under pelagic conditions, whereas marlstones and siltstones could have been emplaced by low-density turbidity currents in a quiet-water environment. Limestones were deposited above the CCD but probably at depths reaching $2 \mathrm{~km}$ at the site (Site 398 Report, this volume).

Acoustic Formation 4, corresponding to upper Barremian to latest uppermost Aptian, consists of sand-siltclay graded sequences interbedded with thick (1 to $10 \mathrm{~m}$ ) slumped beds or debris flows. These sequences resulted from the redeposition of older deposits on submarine slopes and on a subsiding sea floor (de Graciansky et 


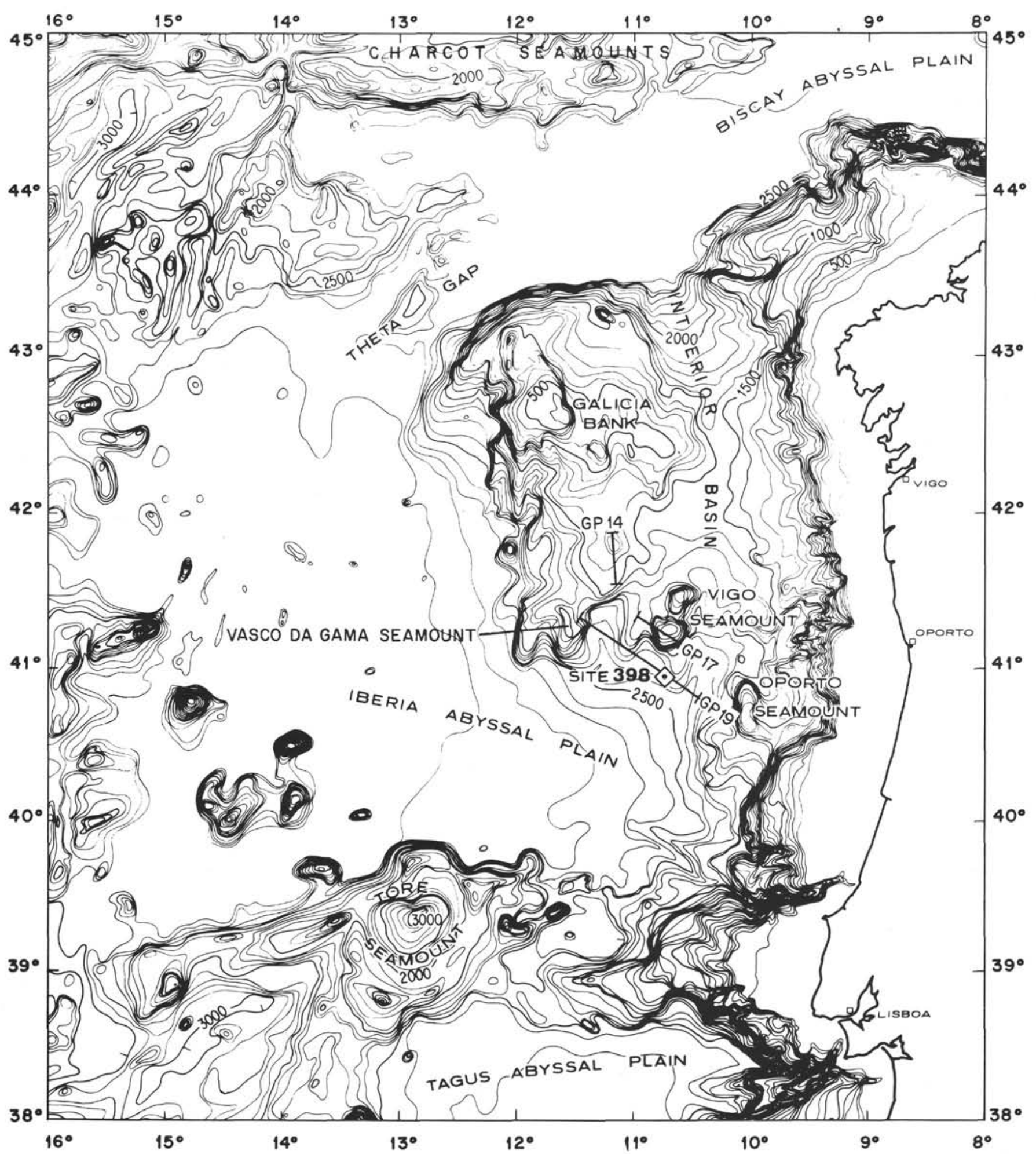

Figure 1. Location of Site 398 and bathymetric map of the Galicia Bank area (Laughton et al., 1975) in corrected fathoms.

al., in press). A stratigraphic break exists in the uppermost Aptian which corresponds both to a sharp lithological change and to a major reflector between Formations 4 and 3 .
Acoustic Formation 3 corresponds to lower Albian to middle Cenomanian. At its base, lower to middle Albian laminated dark shales, mostly of continental provenance, are succeeded by interbedded dark shales 

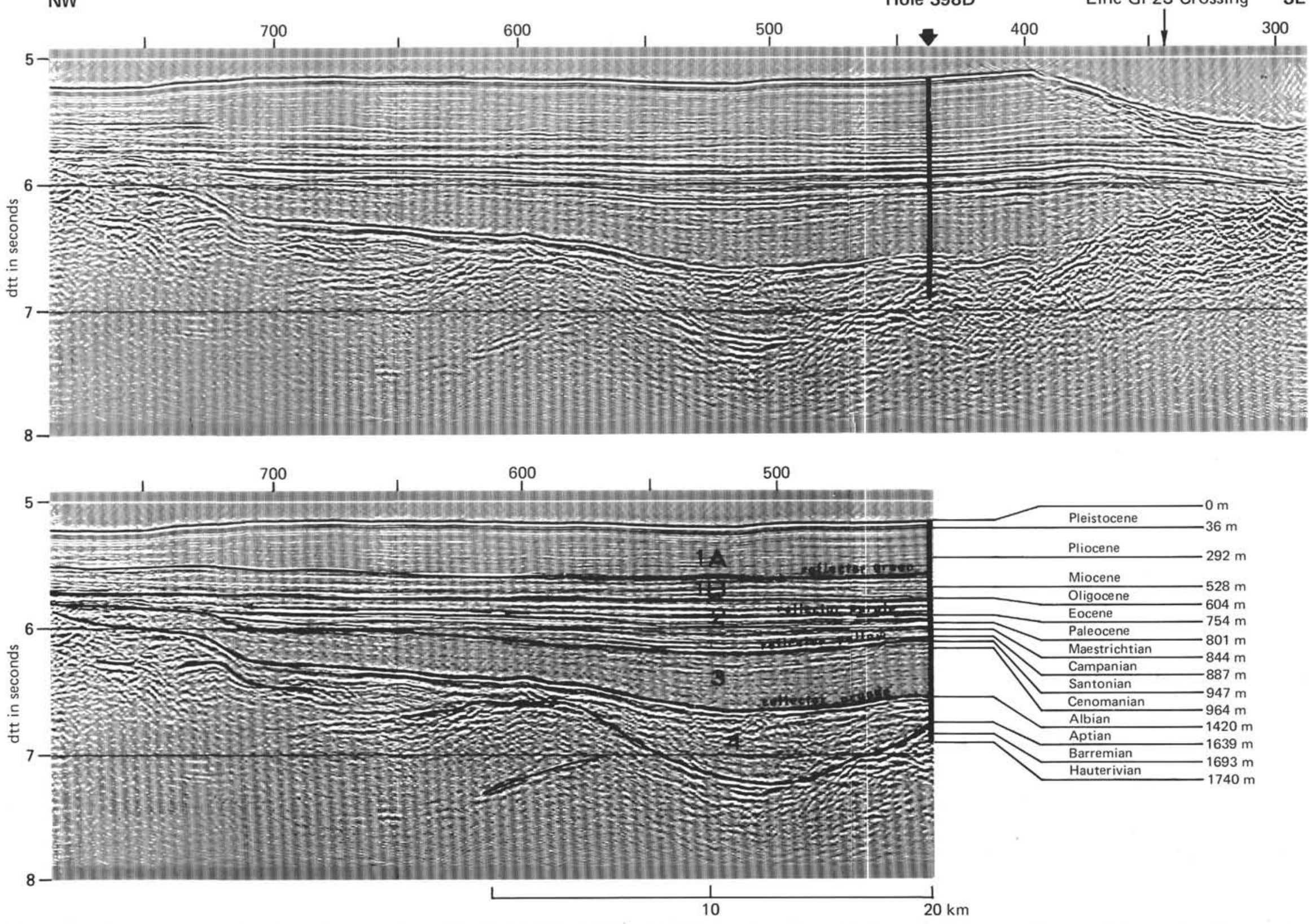

Figure 2. Migrated section of the Flexichoc seismic profile GP 19 (IFP-CNEXO-CEPM) located on Figure 1. Shot numbers are at the top of the profile. Shot spacing: 50 meters. Horizontal scale is in the lower part; vertical scale, in seconds of double travel time. The main seismic reflectors and acoustic units are shown on the interpreted profile. Limits and depths of geological stages (based on Site 398 results) are on the right side. 
and marlstones of middle to upper Albian and by upper Albian to middle Cenomanian redeposited pelagic marl and chalk. Acoustic Formations 3 and 2 are separated by the well-known Cenomanian to lower Senonian hiatus.

Acoustic Formation 2, corresponding to Senonian to upper Eocene, consists of two main lithologic units. Reddish to yellowish brown marly nannofossil chalk, calcareous mudstone, claystone, and siliceous mudstone in the lower part underly siliceous marly nannofossil chalk and mudstone interbedded with turbiditic sandsilt-marl sequences.

Acoustic Formation 1 spans recent to Oligocene sedimentation, and consists of rhythmically bedded marly nannofossil ooze, nannofossil ooze, marly nannofossil chalk, and nannofossil chalk.

\section{MAGNETIC DATA: THE EARLY EVOLUTION OF THE NORTH ATLANTIC}

The sedimentary evolution of this continental margin should be considered in the general context of the kinematic and tectonic evolution of the North Atlantic. All published kinematic solutions for the evolution of the Atlantic north of the Azores-Gibraltar line, and also all reconstructions of continents before their separation (Le Pichon, 1968; Pitman and Talwani, 1972; Laughton, 1972; Le Pichon et al., 1977; Groupe Galice, this volume), are based on magnetic lineations and/or fracture zone trends. As a general rule, the fit of corresponding magnetic anomaly lineations, on each side of the spreading ridge axis, from anomaly 32 (Upper Cretaceous) to the present gives a good idea of the kinematic evolution of the North Atlantic (Pitman and Talwani, 1972; Laughton, 1972). No magnetic data were available to provide other kinematic constraints between the anomaly 32 fit and the pre-opening positions of the continents. These positions were deduced from the shape of the continental margins, the correspondence of trends of the oldest oceanic portions of fracture zones, and of pre-rift linear markers on land (Le Pichon et al., 1977).

Figure 3 presents a new map of magnetic lineations in the northeast Atlantic based on a compilation of published data north of the Charlie-Gibbs fracture zone (Pitman and Talwani, 1972; Kristoffersen and Talwani, 1977), west of anomaly 25 (Williams and McKenzie, 1971; Pitman and Talwani, 1972; Williams, 1975; Laughton et al., 1975; Cande and Kristoffersen, 1977), and on a new re-examination of magnetic profiles east of anomaly 25 (Sibuet et al., in press). Magnetic anomalies 33 and 34 have been identified using the proposed criterion of Cande and Kristoffersen (1977).

A triple junction point probably existed west of the Bay of Biscay at the time of anomalies 33 and 34, as proposed by Williams (1975). Although Late Cretaceous to late Eocene compressive movements have affected the initial configuration of anomalies 33 and 34 in the Bay of Biscay, the shape and amplitude of these anomalies associated with the Charcot-Biscay-Cantabria seamounts do not seem to have been strongly af- fected by this compressive episode. (Sibuet et al., in preparation).

In the Iberian Abyssal Plain, west of the Iberian Peninsula and east of anomaly 34 , magnetic anomalies reach about $150 \mathrm{nT}$. The size and spacing of these anomalies are similar to those of the Cretaceous quiet zone west of North Africa (Hayes and Rabinowitz, 1975). From south to north, the eastern limit of the domain outlined by these anomalies corresponds to the Tore-Madeira rise along the $J$ anomaly (Pitman and Talwani, 1972; Olivet et al., 1976; Rabinowitz et al., 1979), then to a positive anomaly which continues the Tore-Madeira rise to the $41^{\circ} \mathrm{N}$ parallel and which could Correspond to the $M 0$ anomaly, and finally to a line which bounds the northwest corner of Galicia Bank. The $J$ anomaly has been identified with the $M 0$ M1 anomaly (Rabinowitz et al., 1979) dated as late Aptian (Leg 53, Francheteau, personal communication; van Hinte, 1976). If those assumptions are correct, the wide area located between anomaly 34 and this feature should correspond to the Cretaceous quiet magnetic zone. East of this feature, the $M$ sequence would not exist. Nevertheless, this should not necessarily imply that oceanic crust created by sea-floor spreading is lacking east of the $J$ anomaly.

\section{LEG 47B RESULTS IN THE FRAMEWORK OF THE EARLY EVOLUTION OF THE NORTH ATLANTIC}

\section{Triassic-Liassic or Older Tensional Episode}

The first epoch of rifting of continents in the North Atlantic is still being debated. It is thought to be linked to several tensional phases occurring from Permian to late Lias in the continental Eurasian-American framework (e.g., Arthaud and Matte, 1975; Groupe Galice, this volume) and to the early history of the Mesogea (e.g., Aubouin, 1977). Generally, the existence of this rifting eposide is supported by the presence of thick evaporitic series linked to a fast subsidence of continental blocks. Reliable age data around the Iberian Peninsula and Grand Banks exist, especially for the Triassic-Lias episode. On the Grand Banks, Jurassic and older formations are presented in structural basins bounded by block-faulted basement structures and display salt diapirism (Daily Oil Bulletin, 1973). In Aquitaine, TriassicLiassic sedimentation is characteristic of a subsiding basin filled with thick detrital and evaporitic deposits (Winnock, 1971; Dardel and Rosset, 1971; Winnock et al., 1973). In initial reconstructions of continents, the Aquitaine basin could be continued towards the west by grabens and basins related to the Labrador-Biscay Fault (Laughton, 1972; Le Pichon et al., 1971a). In the interior basin (Figure 1) between Galicia Bank and Iberia, the deep sedimentary layers may be Jurassic or older (Groupe Galice, this volume). Nevertheless, the very thick sedimentary series shows no evidence of salt diapirism on seismic profiles and does not indicate that this area has been affected by a Triassic-Liassic episode of rifting. In the smaller basins of the continental slope, however, formations are affected by salt diapirism, as between the Porto seamount and the Portuguese shelf 


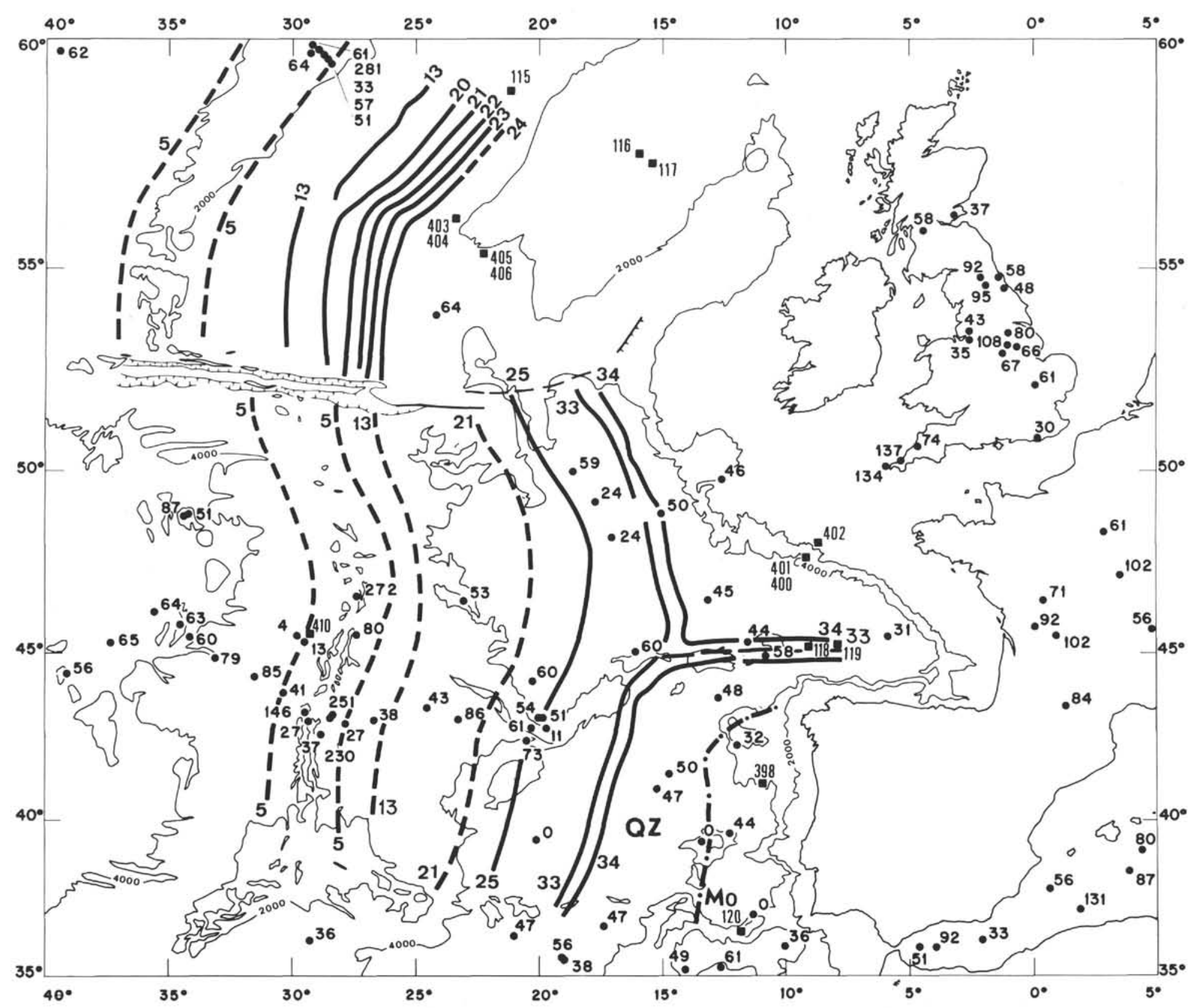

Figure 3. Magnetic lineations in the northeast Atlantic. See text for data sources. Numbered squares correspond to locations and numbers of DSDP sites. 
(Montadert et al., 1974; Wilson, 1975; Groupe Galice, this volume). Consequently, numerous studies support the hypothesis that the initial Eurasian-American continent has been affected, at least locally, by intense fracturing and by an episode of rifting giving rise to subsiding basins filled with Triassic-Liassic evaporites and/or clastic sediments. The westernmost extension of these basins is located east of the Cretaceous quiet magnetic zone (Figure 3), but cannot be traced easily because of the great thickness of sedimentary cover, especially in the Iberian Abyssal Plain south of Galicia Bank. The amount of oceanic crust, if any, which was created during this tensional episode cannot be determined. This crust is probably a mixed type, neither purely oceanic nor purely continental as supported by seismic velocities in similar zones of early opening.

\section{Late Jurassic-Early Cretaceous Tensional Episode}

South of Grand Banks, on the western Scotian shelf, a Berriasian/Valanginian hiatus has been discovered in sediments deposited in a shallow marine environment (Gradstein et al., 1975). On the Grand Banks, the most striking structural feature is a major angular unconformity at the base of the Cretaceous section. Beneath this unconformity, Jurassic and older formations are preserved in structural basins bounded by basement block-faulted structures (Daily Oil Bulletin, 1973). Coeval tensional episodes have been noticed in the Alpine-Mesogean domain (e.g., Aubouin, 1977).

In the Galicia Bank and Vigo Seamount areas, a major tectonic event responsible for the main morphologic trends of the continental margin (Groupe Galice, this volume) occurred in the Late Jurassic-Early Cretaceous. Faulted blocks subsided and rotated along faults of Panamean type. Rotating faults were active on both the Iberian and Armorican margins during this episode (Montadert, Roberts, et al., 1977a). However, since the last 73 meters of core from Site 398 drilled into a half-graben structure seem to have been redeposited above the CCD at a depth up to 2000 meters (Site 398 Report, this volume), it is impossible to evaluate how much vertical motion is associated with each tensional episode. Fan-shaped sedimentary accumulations, observed in acoustic Formation 4 (Figure 2), show that sedimentation occurred during tilting of basement blocks (Site 398 Report; Groupe Galice; both, this volume). Latest Aptian is the age determined from borehole data for the end of the Late Jurassic-Late Cretaceous episode.

The Cretaceous magnetic quiet zone is bounded on the east by the $J$ or $M 0$ anomaly (Figure 3 ). East of this limit, the $M$ sequence is lacking, but a quiet magnetic domain exists and could be related either to a continental subsided area or to the Jurassic magnetic quiet zone (Sibuet et al., in preparation). If these assumptions are correct, this would mean that either the Permian to Lias tensional episode has affected a large area between North America and the Iberian peninsula with oceanization of continental crust, or, more probably, that an early opening of limited extent occurred during the Middle Jurassic after the Permian to Lias tensional episode.
In both hypotheses, as the $M$ sequence is lacking, there is no creation of typical oceanic crust between North America and the Iberian Peninsula in the Early Cretaceous before the late Aptian.

\section{$J$ Anomaly and the Beginning of True Sea-Floor Spreading in the Northern Atlantic}

Following the above events, the history of the Tethyan Ocean becomes independent of the Atlantic evolution. While compressive phases induced the first Alpine deformations, opening of the Atlantic is occurring. A first approximate configuration of the landmasses is given in Figure 4. The relative positions of Africa and North America are well established (personal communication from Shouten, in Rabinowitz et al., 1979). The relative position of the Iberian Peninsula with respect to North America is based on a welldocumented position for the eastern limit of the Cretaceous quiet magnetic zone seaward of the Iberian Peninsula and on some limited identification of the $J$ anomaly using available magnetic profiles located east of Grand Banks (Pitman and Talwani, 1972). In a first attempt, positions of Europe and Rockall are those of the initial fit of Le Pichon et al. (1977). This fit can be improved by using a better shape of $M 0$ anomalies on each side of the northern Atlantic and by including fracture zone constraints, which is not the case in Figure 4. Nevertheless, this new preliminary step in the kinematic evolution of the North Atlantic provides further constraints on the early opening and on the initial fit of continents.

By definition, the $J$ anomaly is associated with topographic features (Pitman and Talwani, 1972) such as the Tore-Madeira rise on the eastern side of the North Atlantic and the " $J$-Anomaly Ridge," south of Grand Banks and the Newfoundland fracture zone. Ballard et al. (1976) have proposed that these $J$ anomaly twin features were associated with an Azores-like hot spot. The formation of these twin structural features, whatever their mode of formation, must have modified both the tectonic evolution of the nearby continental margins and the style of sedimentation. This could explain the change in sedimentation type from the Aptian graded sequences emplaced by turbidity currents to the Albian dark shales and also the presence of the main seismic discontinuity between acoustic Formations 4 and 3 (Figure 2). The middle Aptian dark shales found on the Armorican margin (Montadert, Roberts, et al., 1977a) may have been deposited at an earlier date because the connection between the Iberian Abyssal Plain and the Bay of Biscay was not established north and south of the Flemish Cap-Galicia Bank structural feature at the time of anomaly $J$.

Since latest Aptian, the western continental margin of the Iberian Peninsula has subsided because of vertical cooling of the lithosphere as the accreting boundary moved westward.

\section{Anomaly 34: A Step in the Opening of the North Atlantic}

The trend and length of anomaly 34 on each side of the North Atlantic have been defined from numerous 


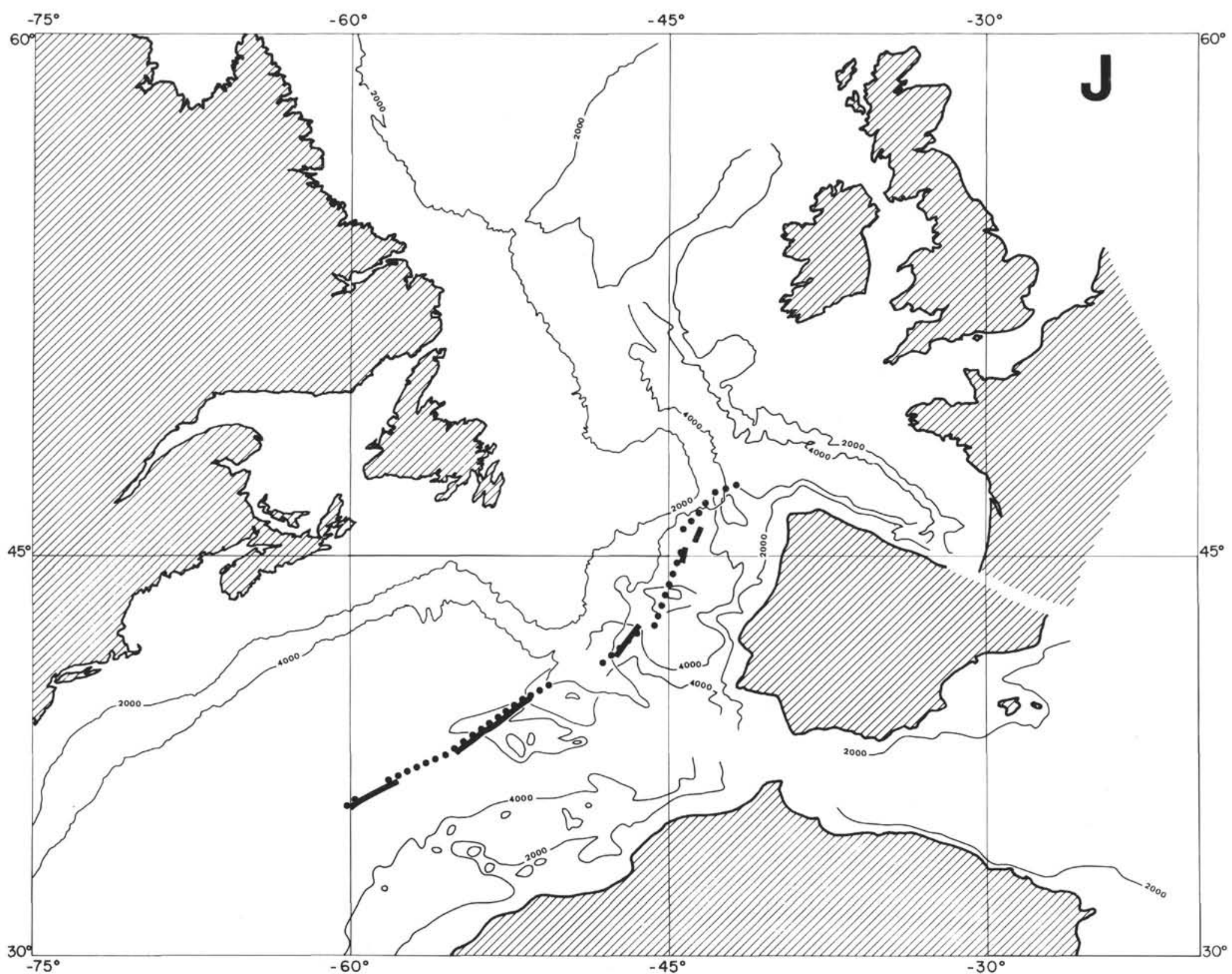

Figure 4. Tentative reconstruction of the positions of the continents at the time of $\mathrm{J}$ anomaly (uppermost Aptian). Bathymetric contours are in meters. America is kept fixed. J anomaly is represented by the dotted line on the eastern side and by the continuous line on the western side of the North Atlantic. 
data. Between the Charlie-Gibbs fracture zone and the Azores-Gibraltar line, it is impossible, using the constraints of these two fracture zones, to match the corresponding plate boundaries at the time of anomaly 34 (upper Santonian in the van Hinte scale [1976]).

Le Pichon and Sibuet (1971), having examined the kinematics of the Eocene episode of compression between the Iberian and European plates, show that the boundary between the two plates extended west of the Pyrenees, along the Spanish marginal trench to end west of King's Trough at a triple junction point. Consequently, the positions of anomalies 34 on each side of this plate boundary have been shifted after their creation. Segments of anomalies 34, located north and south of the Charcot and Biscay seamounts, have been matched without any ambiguity with anomaly 34 on the American side, using the trend constraints of the CharlieGibbs fracture zone and the Azores-Gibraltar line. One of the main kinematic implications is that at the time of anomaly 34, the Bay of Biscay was not completely created. This is supported by the possible presence of anomalies 34 and 33 in the central part of the Bay of Biscay (Williams, 1975; Sibuet et al., in preparation).

In late Santonian time, the open sea is well developed south of the Charlie-Gibbs fracture zone $\left(53^{\circ} \mathrm{N}\right)$. The sudden occurrence of primary minerals formed in upstream soils (illite, chlorite, sandy silicate, kaolinite) from late Santonian to at least early Maestrichtian is probably due to the supply of minerals inherited from high latitudes and transported by the newly established north-south oceanic circulation (Chamley et al., this volume). This oceanic circulation could have been established during the early opening of the Labrador Sea (Le Pichon et al., 1971b) which is at the time of anomaly 34 (Figure 5).

\section{General Evolution of the West Iberian Continental Margin in the Framework of the Early Evolution of the North Atlantic}

Based on arguments which have been developed, the following evolution is tentatively proposed. The West Iberian continental margin was likely created during the Permian Triassic-Lias rifting episode (280 to 174 m.y. B.P.).

A limited oceanic domain (about $100 \mathrm{~km}$ wide) opened between the Iberian peninsula and Grand Banks in the Middle Jurassic (174 to 150 m.y. B.P.). However, no oceanic opening occurred in Late Jurassic-Early Cretaceous (150 to 109 m.y. B.P.) but, simultaneously, a second tensional episode would be responsible for fault-block subsidence and tilting on the West Iberian continental margin. In latest Aptian (109 m.y. B.P.), the main features of the continental margin morphology would have been in place. Since then (109 m.y. B.P.), the continental margin has subsided regionally except in a few zones such as the northern part of Galicia Bank where Late Cretaceous-Tertiary compressive movements have occurred. The decisive opening of the northern Atlantic dates from that time.

\section{MECHANISMS OF FORMATION AND EVOLUTION OF PASSIVE CONTINENTAL MARGINS}

To estimate vertical movements, one must consider the structural and tectonic evolution of a passive continental margin. North of the Azores-Gibraltar line in the North Atlantic where graben-type subsidence occurred prior to splitting in Permian to Lias time, the vertical evolution of continental margins is hidden by the complex posterior evolution which has taken place since Early Cretaceous. Indeed, in the Bay of Biscay and between the Iberian peninsula and Grand Banks, a possible Middle Jurassic limited oceanic opening followed by a Late Jurassic-Early Cretaceous tensional episode has affected the vertical evolution of both the Armorican and West Iberian continental margins.

Several mechanisms to explain the formation and the evolution of continental margins have been proposed (Bott, 1976). Doming of continental crust before and at the time of the break-up of continents is generally not observed according to Kent (1977) except along the Red Sea and the East African rifts. However, thermal response to the emplacement of hot material should cause vertical movements during and after splitting. During the break-up of continents, the thickness of the continental crust along the newly created margin is reduced by subaerial and subcrustal processes. Afterwards, the continental shelf subsides, probably due to the thermal contraction of the lithosphere with a time constant of about 50 m.y. (Sleep, 1971).

Bott and Dean (1972) suggest that differential stress occurs along continental margins and is the result of unequal loading across the margin. This implies a varying stress system between the lower continental crust and the adjacent upper mantle, which causes a migration of lower continental material by creep in the sub-oceanic mantle. This process may cause subsidence of the shelf, which favors normal faulting in the brittle upper continental crust (Bott 1971, 1973). Such a subsidence, intense at the time of splitting, may continue at a decreasing rate indefinitely thereafter.

Subsidence may also occur in response to increased crustal density produced by metamorphic processes such as the gabbro to eclogite transition (Ringwood and Green, 1966; Collette, 1968), or the greenshist to amphibolite transition (Falvey, 1974), or by intrusions of basic or ultrabasic igneous rocks (Beloussov, 1960; Sheridan, 1969). Lithosphere should respond to such variation of the density structure by a lithospheric flexure involving margin subsidence (Walcott, 1972). Recently, Foucher and Sibuet (in press) questioned the validity of this last mechanism and proposed an interpretation of heat-flow data from the Armorican margin compatible with a thinning of the continental crust by creep in the lower part of the crust, the upper brittle part of the crust being affected by Panamean or normal faulting (Montadert et al., 1977b). All of the above mechanisms may contribute to margin subsidence; the problem is to assess their relative importance. 


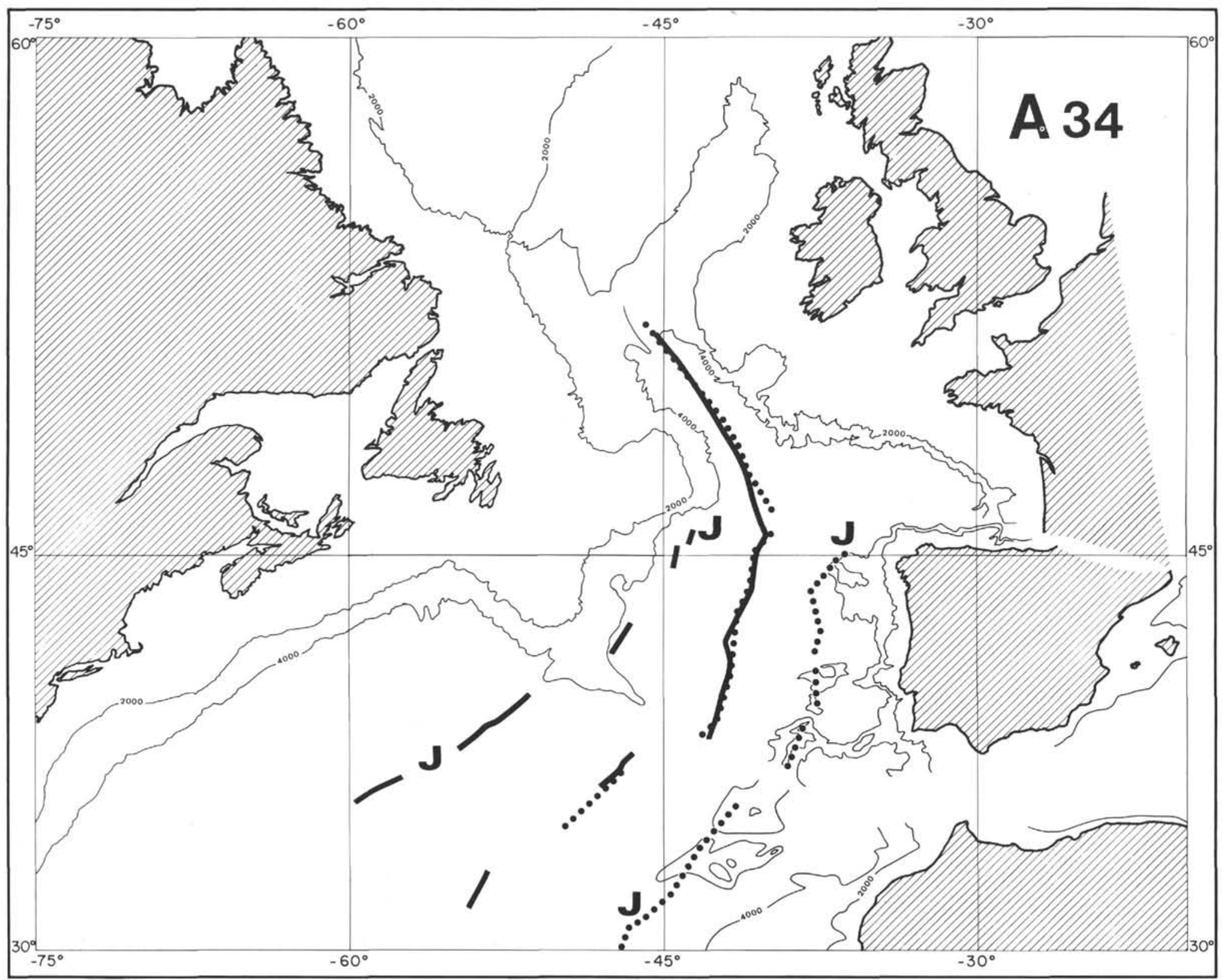

Figure 5. Reconstruction of the position of continents at the time of anomaly 34 (late Santonian). Bathymetric contours are in meters. America is kept fixed. Magnetic anomalies $\mathrm{J}$ and A-34 are represented by the dotted line on the eastern side and by the continuous line on the western side of the North Atlantic. Using conventions of Le Pichon et al. (1976), parameters of rotation are: Europe/North America $63.0^{\circ} \mathrm{N} 149.3^{\circ} \mathrm{E}-19.0^{\circ}$; Iberian peninsula/North America $-82.8^{\circ} \mathrm{N} 121.3^{\circ} \mathrm{E}-22.5^{\circ}$. 


\section{VERTICAL MOVEMENTS AT THE LEVEL OF SITE 398}

The complexity and diversity of proposed mechanisms to explain the formation of continental margins are partly due to the fact that paleodepths across continental margins are unknown. The history of subsidence remains to be unraveled using sedimentological patterns on the sea floor depending on, for example, dissolution and productivity for opal and carbonate, and of surface and deep water circulation. The vertical distribution of benthic faunas allows paleodepth estimation as follows: continental shelf ( 0 to $200 \mathrm{~m})$, upper bathyal ( 200 to $500 \mathrm{~m})$, middle bathyal ( 500 to $1000 \mathrm{~m}$ ), and lower bathyal (1000 to $2000 \mathrm{~m}$ ). In the abyssal domain $(>2000 \mathrm{~m})$, depth distinctions are often impossible.

We will try to show how the Site 398 results, placed in the general context of the West Iberian continental margin evolution can provide constraints about the vertical evolution at Site 398 (Sibuet et al., in press).

Eroded surfaces $2.5 \mathrm{~km}$ deep, unaffected by the Late Jurassic-Early Cretaceous tensional episode, exist both on the Armorican and West Iberian continental margins. Site 398 paleodepth will be estimated using data concerning the vertical evolution of these eroded surfaces.

\section{Eroded Surfaces}

Flat surfaces covered with post-latest Aptian sediments have been identified on the Armorican and West Iberian continental margins at depths ranging from 1.5 to $2.8 \mathrm{~km}$ (Figure 6). These surfaces are horizontal or dip gently toward the ocean. We interpret them as relics of subaerially eroded areas which were at zero depth in pre-latest Aptian time. They are identified on Galicia Bank, on Vigo and Vasco da Gama seamounts (Figure 1 ), and between these features. The depth of these surfaces is at $1.5 \mathrm{~km}$ on Galicia Bank and 2.5 to $2.8 \mathrm{~km}$ elsewhere. Because a subduction zone functioned in the Bay of Biscay, north of Iberia, from Late Cretaceous to Eocene time (Sibuet and Le Pichon, 1971; Le Pichon and Sibuet, 1971; Choukroune et al., 1973), the northern border of Galicia Bank could have been affected by this compressive phase. Depths of these surfaces are consequently constant on the Armorican (Montadert et al., 1977b) and West Iberian continental margins, but not on Galicia Bank itself.

These eroded surfaces have subsided on a regional scale from zero level to their present depth since the beginning of the real opening of the North Atlantic, which is dated as latest Aptian. Isostatic readjustment due to local or flexural loading is minor; sediment cover on the eroded surfaces (Figures 6 and 7) does not exceed $0.8 \mathrm{~km}$. Consequently, the subsidence could be related to the thermal cooling of the lithosphere as the spreading axis moved away.

Several authors suggest that the subsidence of the entire continental margin follows the thermal oceanic subsidence curve since the creation of oceanic domain (Watts and Ryan, 1976; Montadert et al., 1977b). Seismic reflection profiles show that the whole fault pat- tern of the West Iberian continental margin was sealed up since latest Aptian (Groupe Galice, this volume), except locally where tertiary compressive phases took place. Consequently, either the whole margin subsides globally, the vertical motion being consumed at the level of a vertical fault pattern parallel to the margin trend, or the continental margin was flexured, continental and oceanic plates being coupled or not (Figure 8). Because such a fault pattern has not been noted, the second hypothesis seems more probable.

\section{Vertical Evolution at the Level of Site 398}

We have supposed that the subsidence curve of the eroded surface was an exponential type (Figures 9 and 10) and that at the level of Site 398 , located $20 \mathrm{~km}$ south of such an eroded surface, the same subsidence curve could be applied, even if the drill site is $2 \mathrm{~km}$ deeper than the present depth of the eroded surface. Consequently, the paleodepth of the acoustic basement should be at least $2 \mathrm{~km}$ in the Lower Cretaceous, which is compatible with the paleodepth of sediment emplaced at this time (Site 398 Report). The local isostatic readjustment has been calculated using shipboard density measurements (Site 398 Report) (Figure 9). Compaction has been taken into account to calculate the Site 398 paleodepth (Figure 10). The extremes of the CCD curve, superimposed on the paleodepth curve in Figure 10, are arbitrary.

During the ante-latest Aptian evolution, we presume that the acoustic substratum was affected by the two episodes of rifting of Permian-Triassic-Lias and Late Jurassic-Early Cretaceous ages, without knowledge of the relative subsidence contribution of each phase. Between these two phases, during the Middle Jurassic, the West Iberian continental margin could regionally subside by thermal cooling linked to the removal of the heat source (Figure 10).

\section{CONCLUSION}

The paleodepth at the level of a drilling site can only give local information on the vertical evolution of a passive continental margin. Only biostratigraphic data from wells belonging to a transect of the margin linked to structural and tectonic processes could permit quantification of the vertical evolution of a continental margin and the understanding causes of subsidence. If the thermal subsidence seems to be the main cause of the vertical evolution of a continental margin, subsidence due to sediment and water load including sea-level changes must be taken into account.

\section{ACKNOWLEDGMENTS}

Vincent Renard critically reviewed the manuscript and made helpful suggestions.

\section{REFERENCES}

Arthaud, F. and Matte, P., 1975. Late Hercynian wrench faults in Southern Europe and Northern Africa: geometry and nature of deformation, Tectonophysics, v. 25, p. 139-171. 
SW

NE

AISTANCE (km)
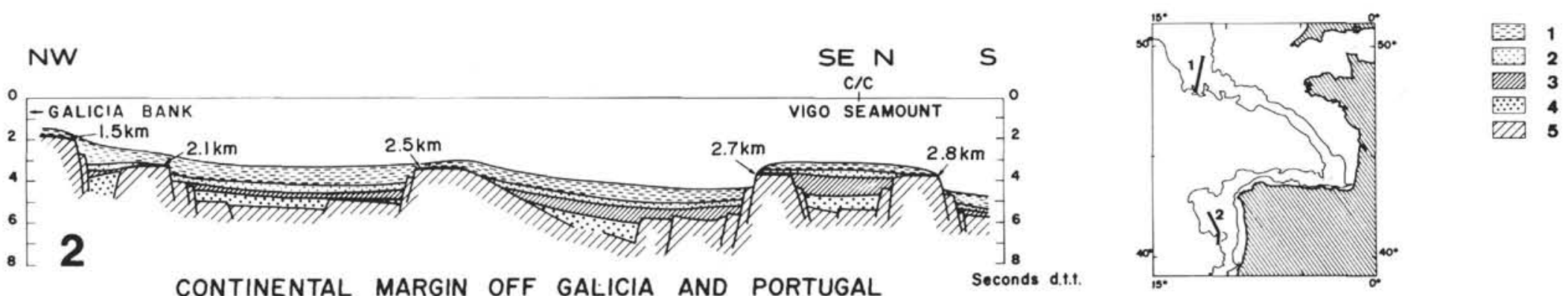

Figure 6. Interpreted seismic profiles obtained on the Armorican and West Iberian continental margins. 1: acoustic Unit 1 (present to Oligocene/Eocene boundary); 2: acoustic Unit 2 (Oligocene/Eocene boundary to Santonian); 3: acoustic Unit 3 (Santonian to latest Aptian); 4: acoustic Unit 4 (ante-latest Aptian); 5: acoustic basement. Eroded surfaces are marked with thick lines and their depths indicated. 

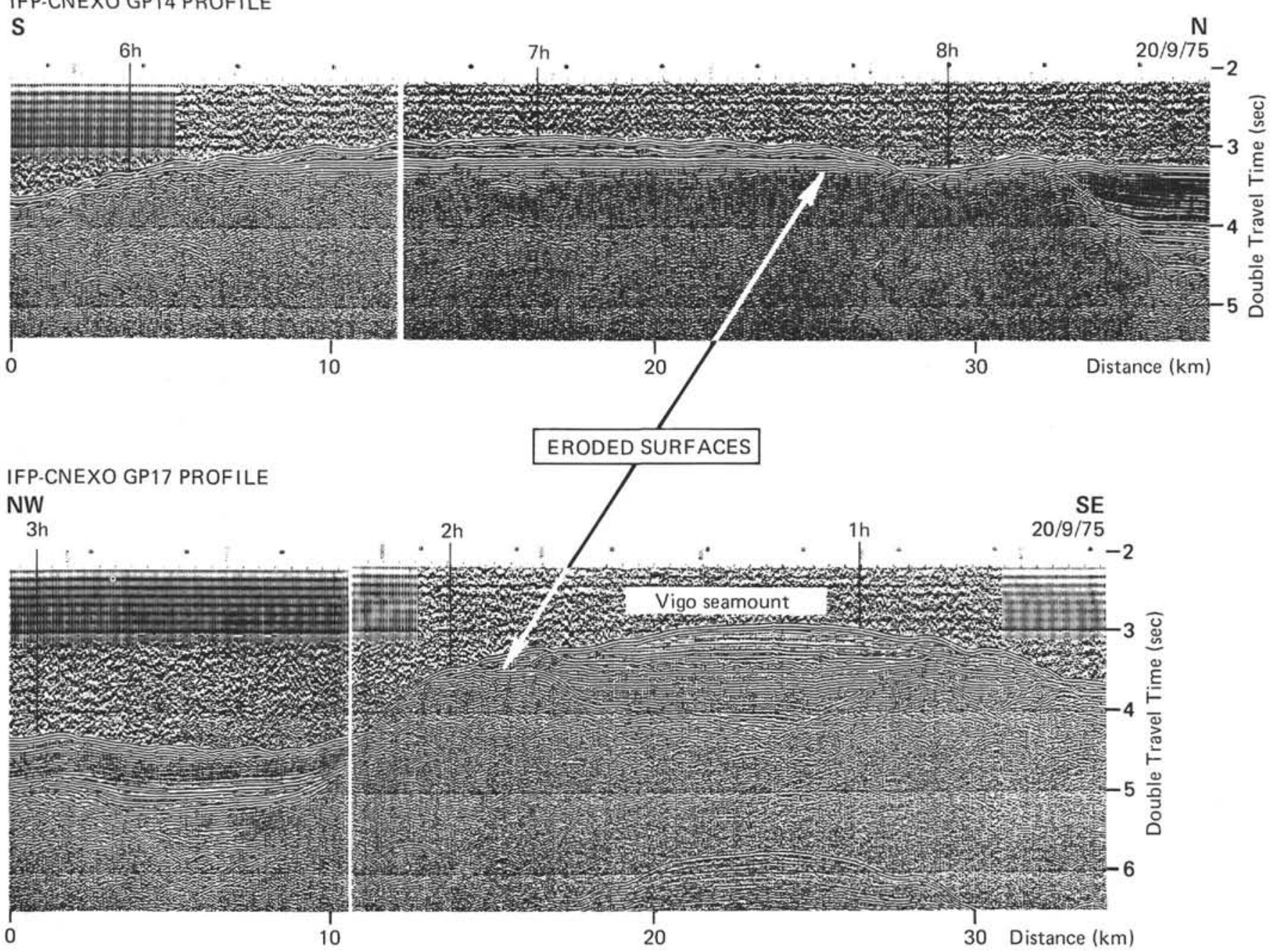

Figure 7. Examples of eroded surfaces at a depth of $2.4 \mathrm{~km}$. Locations of profiles are shown in Figure 1.

Aubouin, J., 1977. Téthys, Atlantique et Pacifique: regard tectonique. Bull. de la Société Géologique de France, v. 4, p. 170-179.

Ballard, J.A., Vogt, P.R., and Egloff, J., 1976. The magnetic " $J$-Anomaly" and associated structures in the North Atlantic (abstract), EOS, v. 57, p. 264.

Beloussov, V.V., 1960. Development of the earth and tectogenesis. J. of Geophys. Res., v. 65, p. 4127-3146.

Bott, M.H.P., 1971. Evolution of young continental margins and formation of shelf basins, Tectonophysics, v. 11, p. $319-327$.

, 1973. Shelf subsidence in relation to the evolution of young continental margins. In Tarling, D.H. and Runcorn, S.K. (Eds.), Implications of continental drift to the earth sciences: London and New York (Academic Press), v. 2 , p. $675-683$.

1976. Problems of the formation and geodynamic development of Atlantic-type continental margins, Anais da Academia Brasileira de Ciencias, v. 48, p. 37-42.

Bott, M.H.P. and Dean, D.S., 1972. Stress systems at young continental margins, Nature Physical Science, v. 235, p. 23-25.
Cande, S.C. and Kristoffersen, Y., 1977. Late Cretaceous magnetic anomalies in the North Atlantic, Earth and Planet. Sci. Lett., v. 35, p. 215-224.

Choukrone, P., Le Pichon, X., Séguret, M., and Sibuet, J.C., 1973. Bay of Biscay and Pyrenees, Earth and Planet. Sci. Lett., v. 18, p. 109-118.

Collette, B.J., 1968. On the subsidence of the North Sea area. In Geology of shelf seas: Edinburg and London (Donovan, Oliver and Boyd), p. 15-30.

Daily Oil Bulletin, 1973 (April 23). Regional Geology of the Grand Banks, p. 1-5.

Dardel, R.A., and Rosset, R., 1971. Histoire géologique et structurale du Bassin de Parentis et de son prolongement en mer. In Histoire structurale du golfe de Gascogne: Paris (Technip), v. 2, p. 1-28.

de Graciansky, P.C., Müller, C., Réhault, J.P., and Sigal, J., in press. Reconstruction de l'évolution des milieux de sédimentation sur la marge continentale ibérique: le flanc sud du haut-fond de Vigo et le forage DSDP IPOD 398. Problèmes de surface de compensation des carbonates. In Séance specialisée de la Société Géologique de France, 12-13 décembre 1977. 

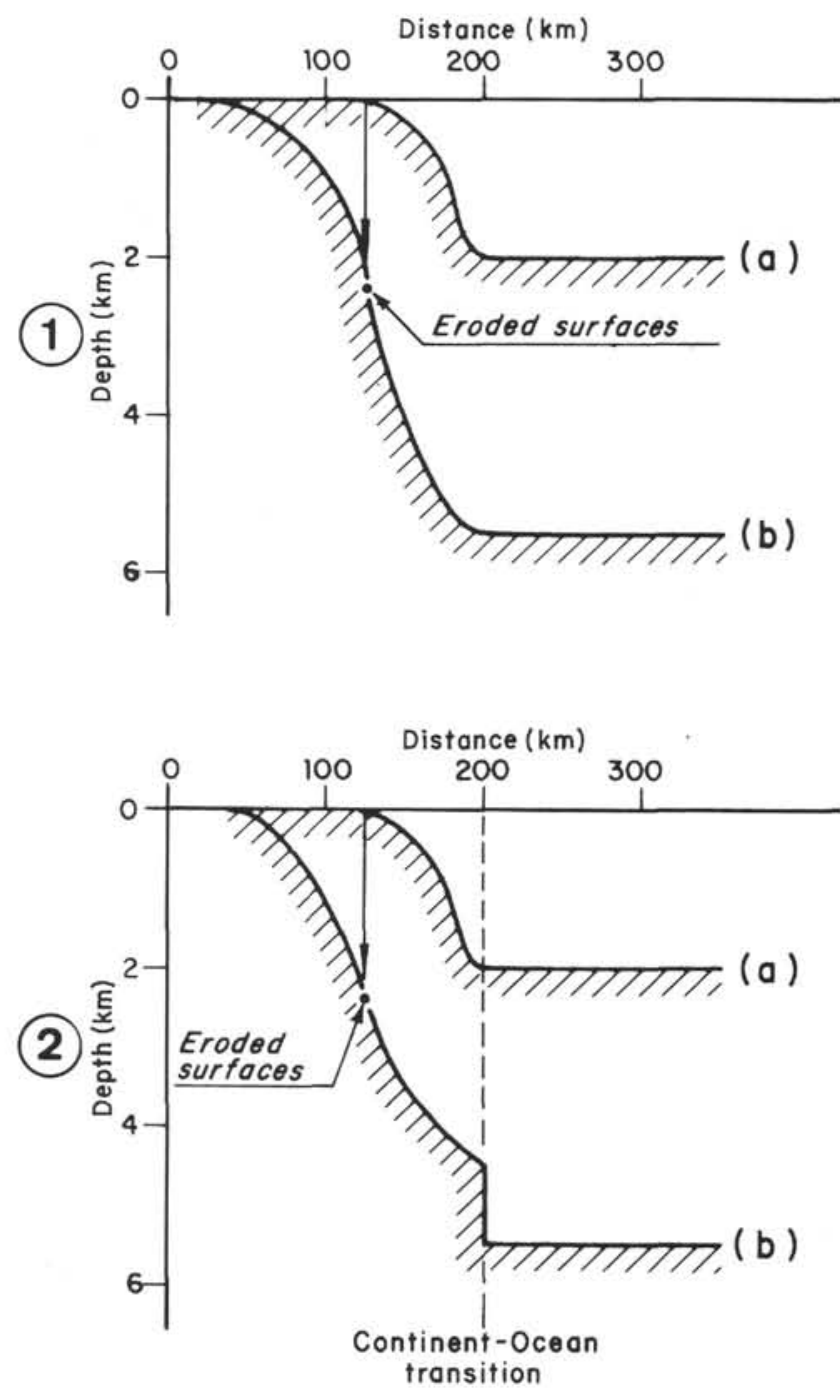

Figure 8. Diagrams showing the vertical evolution of the Armorican and West Iberian continental margin since latest Aptian (a) to the present time (b) in the hypothesis of a flexuring of the continental margin with (1) or without (2) coupling of oceanic and continental crusts. Eroded surfaces at zero level in the Early Cretaceous are actually at $2.4 \mathrm{~km}$.

Dupeuble, P.A., Réhault, J.P., Auxiétre, J.L., Dunand, J.P., and Pastouret, L., 1976. Résultats de dragages et essai de stratigraphie des bancs de Galice et des montagnes de Porto et de Vigo (marge occidentale ibérique), Marine Geology, v. 22 , p. M37-M49.

Falvey, D.A., 1974. The development of continental margins in plate tectonic theory, Australian Petrol. Explor. Assoc., v. 14 , p. 95-106.

Foucher, J.P., and Sibuet, J.C., in press. Thermal models of passive margin evolution, Phil. Trans. of the Roy. Soc. of London.

Gradstein, F.M., Williams, G.L., Jenkins, W.A.M., and Ascoli, P., 1975. Mesozoic and Cenozoic stratigraphy of the Atlantic continental margin, Eastern Canada. In Yorath, C.J., Parker, E.R., and Glass, D.J. (Eds.), Canada's

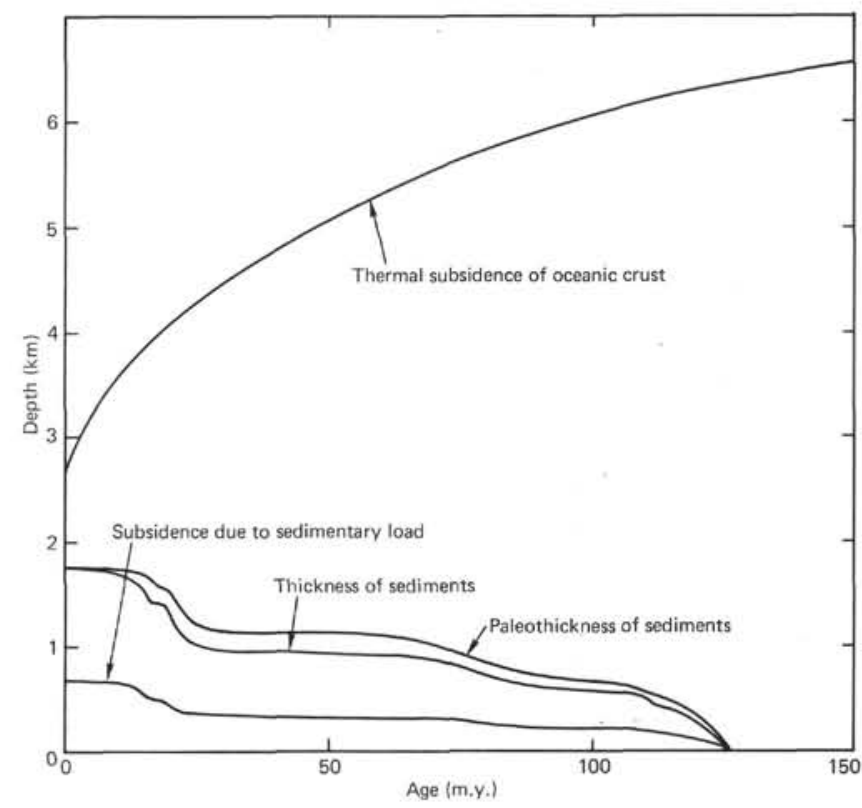

Figure 9. Oceanic subsidence curve after Le Pichon et al. (1976). Sediment thickness, paleothickness of sediments taking into account the compaction of sediments, and local isostatic readjustment due to sedimentary load are calculated as a function of time at the level of Site 398.

continental margins and offshore petroleum exploration: Canadian Society of Petroleum Geologists, Calgary, Alberta, Canada, p. 103-131.

Hayes, D.E. and Rabinowitz, P.D., 1975. Mesozoic magnetic lineations and the magnetic quiet zone off northwest Africa, Earth and Planet. Sci. Lett., v. 28, p. 105-115.

Jansa, L.F. and Wade, J., 1975. Geology of the continental margin off Nova Scotia and Newfoundland. Offshore Geology of Eastern Canada, Canadian Geological Survey Paper 74-30, v. 2, p. 51-105.

Kent, P.E., 1977. Vertical tectonics associated with rifting and spreading (abstract). In The evolution of passive continental margins in the light of recent deep drilling results: Meeting of the Royal Society, London, December 19-20.

Kristoffersen, Y. and Talwani, M., 1977. Extinct triple junction south of Greenland and the Tertiary motion of Greenland relative to North America, Geol. Soc. of Am. Bull., v. 88 , p. $1037-1049$.

Laughton, A.S., 1972. The southern Labrador Sea: a key to the Mesozoic and early Tertiary evolution of the North Atlantic. In Berggren, W.A., Laughton, A.S., et al., Initial Reports of the Deep Sea Drilling Project, v. 12: Washington (U.S. Government Printing Office), p. 1155-1179.

Laughton, A.S., Roberts, D.G., and Graves, R., 1975. Bathymetry of the northeast Atlantic: Mid-Atlantic Ridge to southwest Europe, Deep-Sea Research, v. 22, p. 791-810.

Le Pichon, X., 1968. Sea-floor spreading and continental drift, J. of Geophys. Res., v. 73, p. 3661-3697.

Le Pichon, X. and Sibuet, J.C., 1971. Western extension of boundary between European and Iberian plates during the Pyrenean orogeny, Earth and Planet. Sci. Lett., v. 12, p. 83-88. 


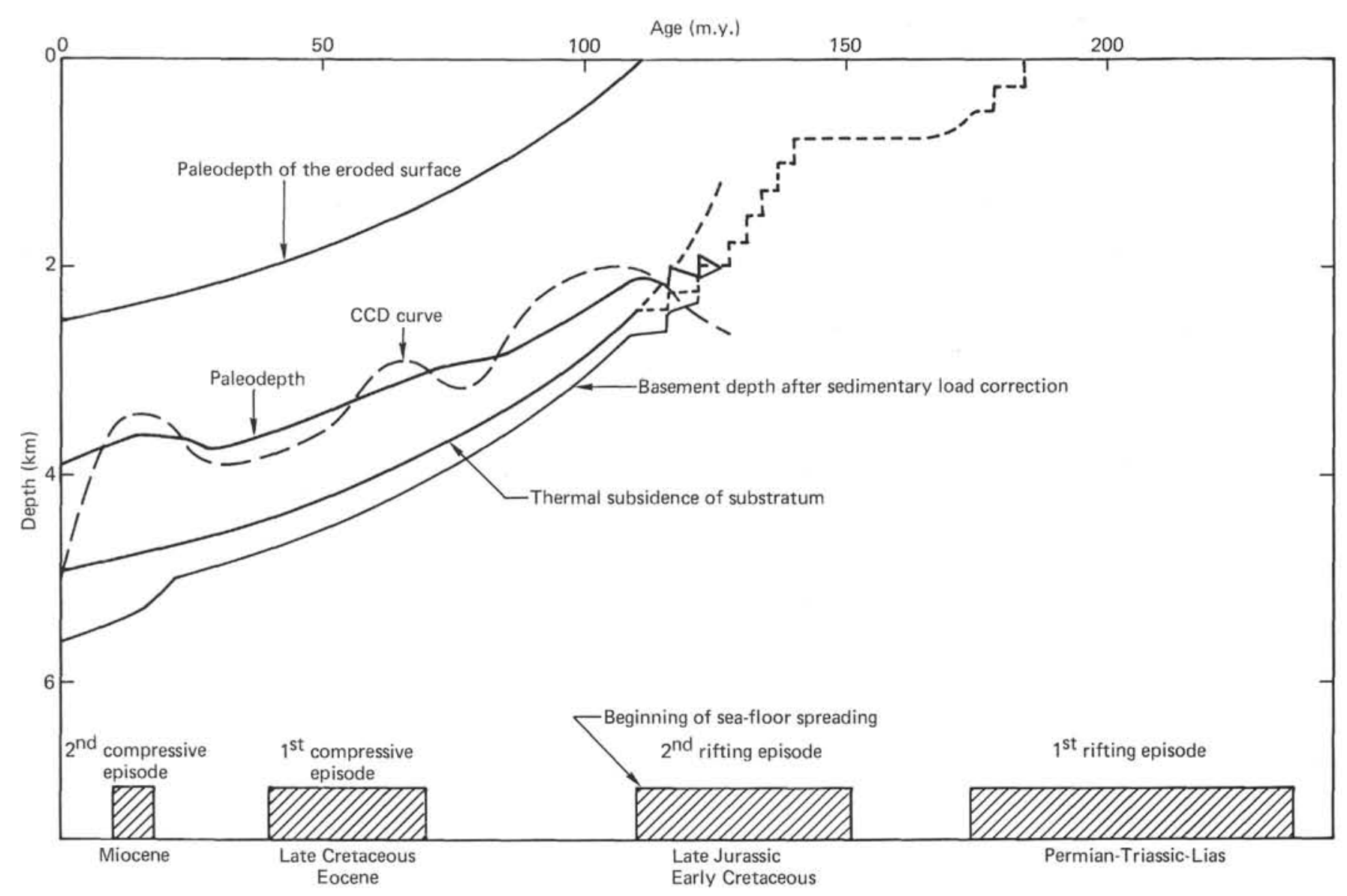

Figure 10. Paleodepth of eroded surfaces since the Early Cretaceous. Proposed paleodepth of the substratum before and after sedimentary load correction and paleodepth at the level of Site 398.

Le Pichon, X., Bonnin, J., Francheteau, J., and Sibuet, J.C., 1971a. Une hypothése d'évolution tectonique du golfe de Gascogne. In Debyser, J. et al. (Eds.), Histoire structurale du Golfe de Gascogne: Paris (Technip), v. 2, p. 1-44.

Le Pichon, X., Hyndman, R., and Pautot, G., 1971b. Geophysical study of the opening of the Labrador Sea, J. of Geophys. Res., v. 76, p. 4724-4743.

Le Pichon, X., Francheteau, J., and Bonnin, J., 1976. Plate tectonics. In Developments in Geotectonics: Amsterdam, (Elsevier), v. 6, p. 1-300.

LePichon, X., Sibuet, J.C., and Francheteau, J., 1977. The fit of the continents around the North Atlantic ocean, Tectonophysics, v. 38, p. 169-209.

Montadert, L., Winnock, E., Delteil, J.R., and Grau, G., 1974. Continental Margins of Galicia-Portugal and Bay of Biscay. In Burk, C.A., and Drake, C.L. (Eds.), The geology of continental margins: New York (SpringerVerlag), p. 323-342.

Montadert, L., Roberts, D.G., Auffret, G.A., Bock, W.O., Dupeuble, P.A., Hailwood, E.A., Harrison, W., Kagami, H., Lumsden, D.N., Müller, C., Schnitker, D., Thompson, R.W., Thompson, T.L., and Timofeev, P.P., 1976. Glomar Challenger sails on Leg 48, Geotimes, v. 21, p. 19-23.

Montadert, L., Roberts, D.G., et al., 1977a. The nature of the continent-ocean boundary, Biscay and Rockall (abstract). Meeting on the Evolution of passive margins in the light of recent deep drilling results, London, October 19-20.
Montadert, L., Roberts, D.G., Auffret, G.A., Bock, W. Dupeuble, P.A., Hailwood, E.A., Harrison, W., Kagami, H., Lumsden, D.N., Müller, C., Schnitker, D., Thompson, R.W., Thompson, T.L., and Timofeev, P.P., $1977 \mathrm{~b}$. Rifting and subsidence on passive continental margins in the North-East Atlantic, Nature, v. 268, p. 305-309.

Olivet, J.L., Pastouret, L., Auzende, J.M., and Auffret, G.A., 1976. Armorican margin evolution in relation with the Bay of Biscay genesis (abstract), Coll. IUSGS Durham, April 1976.

Pitman, W.C., III, and Talwani, M., 1972. Sea-floor spreading in the North Atlantic, Geol. Soc. of Am. Bull., v. 83, p. 619-646.

Ringwood, A.E. and Green, D.H., 1966. An experimental investigation of the gabbro-eclogite transformation and some geophysical consequences, Tectonophysics, v. 3, p. 383-427.

Rabinowitz, P.D., Cande, S.C., and Hayes, D.E., 1979. The $J$ anomaly in the Central North Atlantic Ocean. In Tucholke, B., Vogt, P. et al., Initial Reports of the Deep Sea Drilling Project, v. 43: Washington (U.S. Government Printing Office), p. 879-886.

Sheridan, R.E., 1969. Subsidence of continental margins, Tectonophysics, v. 7, p. 219-229.

Sibuet, J.C. and Le Pichon, X., 1971. Structure gravimétrique du golfe de Gascogne et le fossé marginal nord-espagnol. In Debyser, J. et al. (Eds.), Histoire structurale du Golfe de Gascogne: Paris (Technip), v. 9, p. 1-27.

Sibuet, J.C., Ryan, W.B.F., Arthur, M., Barnes, R., Blechsmidt, G., de Charpal, O., de Graciansky, P.C., Habib, D., Iaccarino, S., Johnson, D., Lopatin, B.F., Mal- 
donaldo, A., Montadert, L., Moore, D.G., Morgan, G.E., Mountain, M., Réhault, J.P., Sigal, J., and Williams, C.A., in press. Deep drilling results of Leg 47B (Galicia Bank area) in the framework of the early evolution of the North Atlantic ocean, Phil. Trans. of the Roy. Soc. of London. Sibuet, J.C., de Charpal, O., Montadert, L., and Ryan, W.B.F., in press. Mouvements verticaux dans le région des bancs de Galice (Atlantique Nord-Est) d'après les résultats du Leg 47B. In Séance spécialisée de la Société Géologique de France, 12-13 décembre 1977.

Sleep, N.H., 1971. Thermal effects of the formation of Atlantic continental margins by continental break up, Geophys. J. of the Roy. Astron. Soc., v. 24, p. 325-350.

van Hinte, J.E., 1976. A Cretaceous time scale, Am. Assoc. of Petrol. Geol. Bull., v. 60, p. 498-516.

Walcott, R.I., 1972. Gravity, flexure and the growth of sedimentary basins at a continental edge, Geol. Soc. of Am. Bull., v. 83 , p. $1845-1848$.
Watts, A.B. and Ryan, W.B.F., 1976. Flexure of the lithosphere and continental margin basins, Tectonophysics, v. 36 , p. $25-44$.

Williams, C.A., 1975. Sea-floor spreading in the Bay of Biscay and its relationship to the North Atlantic, Earth and Planet. Sci. Lett., v. 24, p. 440-456.

Williams, C.A. and McKenzie, D.P., 1971. The evolution of the North-East Atlantic, Nature, p. 232, p. 168-173.

Wilson, R.C.L., 1975. Atlantic opening and mesozoic continental margin basins of Iberia, Earth and Planet. Sci. Lett., v. 25 , p. $33-43$.

Winnock, E., 1971. Géologie succincte du Bassin d'Aquitaine (contribution à l'histoire du Golfe de Gascogne). In Debyser, J. et al. (Eds.), Histoire structurale du Golfe de Gascogne: Paris (Technip), v. 1, p. 1-30.

Winnock, E., Fried, E., and Kieken, M., 1973 Les caractéristiques des sillons aquitains, Bulletin de la Société Géologique de France, v. 1, p. 1-76. 